\title{
SISTEM INFORMASI PENJUALAN VOUCHER HANDPHONE MKIOS PADA PT. BINTANG GLOBAL SUMBER SARANA BANJARMASIN
}

\author{
Yusup Indra Wijaya \\ Fakultas Teknologi Informasi \\ Universitas Islam Kalimantan Muhammad Arsyad Al Banjari Banjarmasin \\ email: yusupindra1313@gmail.com
}

\begin{abstract}
Abstark
Saat ini, perkembangan teknologi begitu maju, dan salah satu yang memanfaatkan kecanggihan teknologi adalah perusahaan. PT. Bintang Global Sumber Sarana merupakan suatu perusahaan yang bergerak pada bidang telekomunikasi yang menjual produk - produk seperti voucher gesek, voucher elektronik, handphone baru bergaransi resmi, dan kartu perdana yang dapat dijual secara grosir maupun eceran. Untuk Sistem penjualan produk - produknya sudah lumayan baik tetapi karena sistem penjualan voucher elektronik khusus menangani mkios telkomsel ini masih manual dan tidak memiliki sistem secara khusus sistemnya yaitu menggunakan buku catatan untuk mencatat rekap penjualan dan Microsoft excel untuk membuat laporan stok harian serta program gabungan yang berbasis DOS untuk membuat faktur penjualan. Sehingga dibuatlah sistem yang baru yang secara khusus menangani inventory penjualan voucher handphone mkios telkomsel ini. Aplikasi ini meliputi transaksi pembelian, transfer antar gudang, transaksi penjualan, transaksi pelunasan, dan laporan - laporan yang mendukung seperti laporan pembelian, penjualan, transfer antar gudang, pelunasan, stok masuk, stok keluar, stok akhir, piutang dan jatuh tempo, peringkat pelanggan, data statistik, laba - rugi beserta input dan laporan master data seperti data pelanggan, voucher, supplier dan gudang agar dapat menjadi sistem yang fleksibel dan komplek. Aplikasi yang dibangun diharapkan dapat bermanfaat bagi Starindo Banjarmasin untuk mempermudah sistem inventory penjualan voucher handphone mkios telkomsel melalui komputerisasi secara khusus dan terarah menangani mkios. Agar dapat menghasilkan informasi yang cepat, tepat dan akurat tanpa memakan waktu dan tenaga yang lama.
\end{abstract}

Keywords: Aplikasi Penjualan MySQL, Visual Basic 6.0, MKios Inventory

\section{PENDAHULUAN}

Semakin hari semakin maju teknologi, perkembangan teknologi yang tiada henti membuat kehidupan menjadi tambah maju dan berkembang sangat pesat. Apabila perkembangan tersebut tidak diikuti maka semakin ketinggalan masalah teknologi ini dirasakan dalam kehidupan sehari-hari. Sekarang ini komputer adalah alat bantu manusia yang sangat membantu sekali baik dalam pemakaian pribadi maupun instansi. Perkembangan teknologi yang tinggi sebaiknya diimbangi dengan ilmu pengetahuan yang tinggi pula. Agar keduanya saling dapat berjalan secara beriringan dan memberikan kelebihannya masing - masing, sehingga dapat menciptakan sesuatu yang berguna dan bermanfaat bagi semua.
Suatu pekerjaan yang manual sebaiknya dijadikan otomatis, sehingga dapat memberikan kemudahan kepada yang menggunakannya. Salah satu kelebihan komputer adalah dapat menyimpan ingatan yang banyak tanpa ada lupa, tidak halnya seperti manusia yang dapat lupa terhadap sesuatunya karena terlalu banyak yang dipikirkan olehnya. Komputer haruslah dijadikan sahabat yang baik agar dapat saling membantu terhadap kekurangan - kekurangan yang dimiliki dan memberikan kelebihankelebihan yang dimiliki, sehingga menjadikan sesuatu itu menjadi lengkap dan saling melengkapi.

PT. Bintang Global Sumber Sarana Banjarmasin yang biasanya disebut Starindo Banjarmasin adalah termasuk salah satu bidang usaha resmi yang bergerak pada Bidang Telekomunikasi yaitu tempat penjualan 
Handphone baru Bergaransi Resmi, Penjualan isi ulang voucher fisik Simpati, Kartu As dan Flexi, Penjualan isi ulang elektronik Simpati dan Kartu As / Mkios, Accesoris Resmi Nokia, serta penjualan Perdana Simpati, Kartu As dan Flexi. Penjualan dapat berupa Grosir dan Eceran. Starindo Banjarmasin adalah Dealer Resmi Telkomsel dan Telkom sehingga sebagian besar kebanyakan produk yang dijual adalah dari Telkomsel dan Telkom. Dilihat dari segi sistem penjualan di Starindo ini memang sudah memiliki sistem yang baik, tetapi pada sistem penjualan voucher Mkios dirasakan kurang karena pada penjualan voucher Mkios ini hanya menggunakan buku catatan dan microsoft excel dan juga tanpa menggunakan sistem database komputer.

Berdasarkan latar belakang yang telah diuraikan di atas, maka dipandang perlu adanya sebuah program komputer untuk mengatasi masalah tersebut, oleh karena itu maka dalam skripsi ini mengangkat judul "SISTEM INFORMASI PENJUALAN VOUCHER HANDPHONE MKIOS PADA PT. BINTANG GLOBAL SUMBER SARANA BANJARMASIN".

\section{Rumusan Masalah}

Dari latar belakang yang ada, maka didapatkan permasalahan sebagai berikut, yaitu bagaimana membuat sebuah program komputer yang memiliki database yang lengkap yang berhubungan langsung dengan Sistem Penjualan Voucher Mkios Telkomsel yang dapat memberikan suatu sistem infomasi kepada PT. Bintang Global Sumber Sarana Banjarmasin dalam pengambilan keputusan yang cepat dan tepat.

\section{Tujuan Penelitian}

Tujuan penelitian pembuatan Sistem Informasi Penjualan Voucher Handphone Mkios Telkomsel Pada PT. Bintang Global Sumber Sarana Banjarmasin adalah sebagai berikut :

1. Dapat mengetahui sistem informasi penjualan yang lengkap terhadap voucher Mkios Telkomsel ini dengan melihat langsung perbandingannya dalam bentuk grafik dan tabel yang bisa dilihat per periode tertentu.
2. Dapat memberikan gambaran untuk pengambilan keputusan yang cepat dan tepat terhadap jumlah voucher - voucher yang akan diorder kepada Telkomsel untuk order yang akan datang.

3. Memberikan informasi yang cepat, jelas dan akurat terhadap penjualan voucher handphone mkios telkomsel ini mengalami laba atau rugi beserta jumlahnya.

4. Untuk menerapkan ilmu yang sudah didapat selama perkuliahan dan menambah pengetahuan serta dapat menambah kreatifitas berpikir dalam menyelesaikan suatu masalah.

\section{Manfaat Penelitian}

Manfaat dari pembuatan sistem informasi ini adalah sebagai berikut :

1. Memberikan kemudahan kepada pegawai yang bertugas.

2. Memudahkan dalam bertransaksi secara teatur dan terarah.

3. Memberikan suatu sistem informasi yang jelas, cepat dan akurat.

\section{METODE PENELITIAN}

\section{Tahapan Penelitian}

Adapun tahapan yang dilakukan dalam penyusunan skripsi ini adalah sebagai berikut :

1. Menentukan Objek Penelitian

2. Menentukan Topik Permasalahan

3. Pengamatan Objek dan Pengumpulan Data

4. Analisa dan Desain Sistem

5. Pembuatan Program

6. Uji Coba Program

7. Perawatan dan Perbaikan Program

8. Penyusunan Laporan

9. Revisi Laporan

10. Pengujian Hasil Laporan

\section{Pengumpulan Data}

Untuk memudahkan penulisan dalam menyusun penelitian ini, digunakan metode yang dapat membantu dalam mengumpulkan dan menganalisa data yang diperoleh, antara lain :

1) Pengamatan Langsung (Observasi)

Pengamatan langsung merupakan pengumpulan data yang dilakukan langsung ke lokasi tempat penelitian yang sedang berlangsung transaksi penjualan. Penelitian ini 
hanya melihat dan mengamati secara langsung bagaimana proses penjualan voucher handphone mkios telkomsel tersebut.

2) Penelitian Kepustakaan (Library Research) Untuk melengakapi data yang diperoleh dari penelitian lapangan maka melengkapinya dengan membaca dan mempelajari buku (literatur) yang ada hubungannya dengan masalah yang akan dibahas, dimana data yang ada akan dihubungkan dengan apa yang ada didalam buku yang jadi panduan. Karena di sini mengupas proses inventory maka lebih ditekankan membaca buku - buku tentang Aplikasi penjualan, Analisis dan Desain Sistem Informasi, Bahasa Pemrograman Visual Basic 6.0, dan Database MySQL serta Statistika.

3) Wawancara (Interview)

Penelitian wawancara merupakan pengumpulan data yang dilakukan langsung ke lokasi tempat penelitian. Disini langsung bertanya pada operator mkios yang memegang chip sub dealer (SD), karena pada dasarnya operator ini lah yang memegang peranan penting pada transaksi penjualan voucher handphone mkios telkomsel ini. Yang ditanyakan kepada operatornya meliputi tentang bagaimana pendaftarannya dan syaratsyaratnya, harga vouchernya, bagaimana proses transfer vouchernya, bagaimana proses penjulannya, bagaimana pembayarannya, dan sistem yang sedang berjalan.

\section{Sistem yang sedang berjalan}

Sebelum mengembangkan sistem yang baru maka terlebih dahulu harus paham terhadap sistem yang telah ada, hal ini dilakukan untuk mengetahui kekurangan kekurangan yang terjadi dan masalah-masalah yang ditemukan pada sistem tersebut. Penelitian ini difokuskan untuk mengetahui terhadap masalah yang berhubungan dengan pengolahan data penjualan Voucher Handphone Mkios Telkomsel.

Sistem yang sedang berjalan pada PT. Bintang Global Sumber Sarana Banjamasin untuk penjualan Voucher Handphone MKios Telkomsel masih manual, dilihat dari segi transaksi hanya menggunakan buku catatan untuk mencatat order penjualan sekaligus mencatat voucher yang terjual dan Microsoft excel untuk membuat laporan penjualan dan stok harian serta menyimpan data - data pelanggan. Pembuatan notanya pun tidak langsung karena ada program gabungan tentang penjualan yang khusus untuk membuat nota dan membuat nota ini pun harus menginputkan lagi nama pelanggan, harga jual dan yang lainnya jadi setiap pembuatan 1 nota saja memelukan inputan yang banyak, sehingga ini dirasakan kurang optimal dan tidak otomatis serta membuat pekerjaan yang bisa dikerjakan 1 kali menjadi berkali - kali bahkan terus berulang kali. Selain itu Dalam transaksi penjualan secara non tunai ini pun dinilai kurang baik dan kurang efisien karena tidak ada laporan yang jelas, akurat dan langsung tentang piutang dan jatuh temponya karena hanya dengan melakukan pengecekan manual pada faktur faktur penjualan yang telah dicetak pada saat transaksi.

Berikut adalah Diagram Konteks untuk sistem yang sedang berjalan :

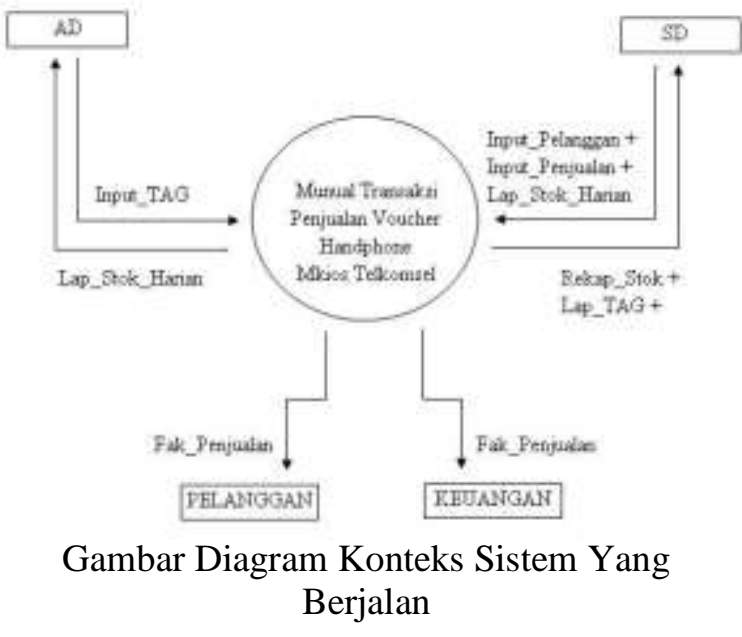

\section{Sistem yang Diusulkan}

Setelah mempelajari dan memahami sistem yang sedang berjalan tampak dengan jelas bahwa sistem yang ada sekarang masih perlu dikembangkan ke arah yang lebih baik. Sehingga apabila masih digunakan sistem yang lama, maka proses inventory menjadi kurang cepat dan akurat dalam pengolahan data - data dan pengelolaannya, oleh karena itu diperlukan sistem yang lebih baik agar efisiensi waktu, tenaga, pikiran dan biaya dapat tercapai, serta untuk mengatasi kerusakan dan kehilangan data yang akan menimbulkan dampak yang cukup besar bagi karyawan yang bekerja dibidang yang bersangkutan, serta bagi perusahaan itu 
sendiri. Untuk mengatasi hal tersebut maka dirancang sebuah sistem yang baru yang diharapkan dapat membantu perusahaan untuk mendapatkan informasi, serta untuk menghasilkan laporan yang up to date dan berdaya guna mengenai hasil penjualan produk seperti laporan pembelian, laporan transfer antar gudang, laporan penjualan, laporan data data statistik, laporan pelanggan, laporan peringkat pelanggan, laporan laba rugi. Selain laporan yang cepat dan akurat dicetak dari segi input data - datanya juga sangat mudah, cepat dan terorganisir dengan baik serta aman dengan cara membackup databasenya secara rutin dan teratur.

Dari pemahaman masalah - masalah yang ada pada sistem yang telah berjalan sekarang maka akan dibuat pemecahan masalah yang dapat dilihat di diagram konteks berikut sebagai sistem yang diusulkan. Diagram konteks dapat di lihat pada gambar berikut :

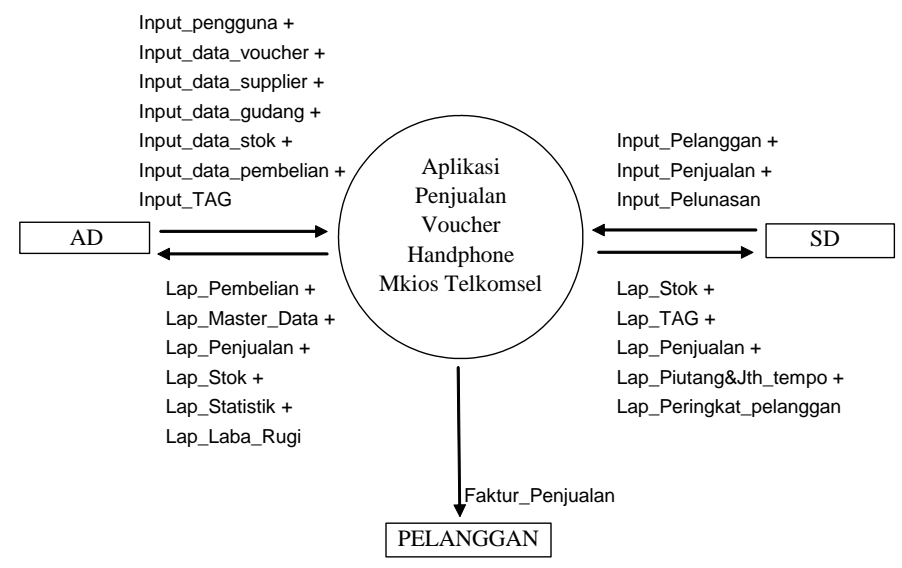

Gambar Diagram Konteks Sistem Yang Diusulkan

Dari Diagram Konteks di atas dapat digambarkan bahwa AD menginputkan data master seperti data voucher, data gudang, data supplier dan juga menginputkan data pengguna, stok awal, data pembelian, dan data transfer antar gudang. Selain itu, tugas SD menginputkan data pelanggan, menginputkan data penjualan dan pelunasan, sehingga $A D$ akan mendapatkan laporan pembelian, laporan master data, laporan penjualan, laporan stok, laporan statistik dan laporan laba rugi, dan juga SD akan mendapatkan laporan stok, laporan transfer antar gudang, laporan penjualan, laporan piutang dan jatuh tempo dan laporan peringkat pelanggan. Setiap melakukan transaksi penjualan, pelanggan bisa langsung mendapatkan faktur penjualan baik pembelian tunai maupun non tunai.

\section{HASIL DAN PEMBAHASAN Hasil Penelitian}

\section{Tampilan Menu Utama}

Menu Utama itu terdiri dari Berkas yang berisi: master data seperti data supplier, data pelanggan, data voucher, dan data gudang. Stok, log off dan keluar. AD Transaksi yang terdiri dari transaksi pembelian dan transfer antar gudang. SD transaksi terdiri dari transaksi penjualan dan transaksi pelunasan. Laporan yang terdiri dari master data yaitu seperti laporan data supplier, pelanggan, voucher dan gudang, laporan stok seperti stok masuk, stok keluar dan stok akhir, laporan AD Transaksi yang terdiri dari laporan pembelian dan laporan transfer antar gudang, laporan SD Transaksi seperti laporan penjualan, laporan piutang dan jatuh tempo, laporan laba rugi ada rs dan sdb, laporan statistik ada grafik dan tabel dan yang terakhir adalah laporan peringkat pelanggan. Pengaturan yang terdiri dari data pengguna dan ubah password serta reset nomor faktur. Dan yang terakhir adalah menu bantuan program yang filenya berbentuk .chm yang dibuat dari software HelpMaker. Selain itu di menu utama ini juga terdapat pengaturan bahasa yang ingin digunakan. Tampilan Menu Utama ditunjukan oleh gambar berikut:

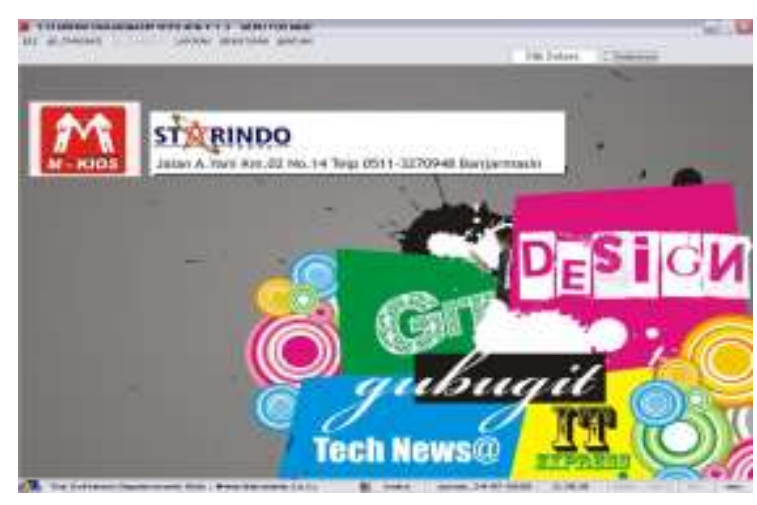

Gambar Menu utama

\section{Tampilan Login}

Tampilan login berfungsi sebagai autentifikasi user kedalam sistem. Hal ini perlu 
agar hanya user yang diijinkan saja yang dapat masuk ke dalam sistem. Dalam form ini, setelah user memasukkan user name dan password dengan benar, klik tombol Work, maka user tersebut aka masuk ke dalam sistem utama. User dapat mengakses sistem ini sesuai dengan tingkatan apakah sebagai administrator, master umum dan master biasa. Tingkatan administrator adalah tingkatan yang bisa mengakses semua menu, sedangkan master umum akan bisa mengakses seluruh sistem ini kecuali sd transaksi dan data pelanggan, dan master biasa hanya bisa mengakses bagian tertentu saja yang terdapat di dalam sistem ini seperti data pelanggan, sd transaksi yang terdapat transaksi penjualan dan transaksi pelunasan, ubah password pengguna dan melihat isi semua laporan - laporan yang terdapat pada sistem. Tampilan login ditunjukan oleh gambar ini.

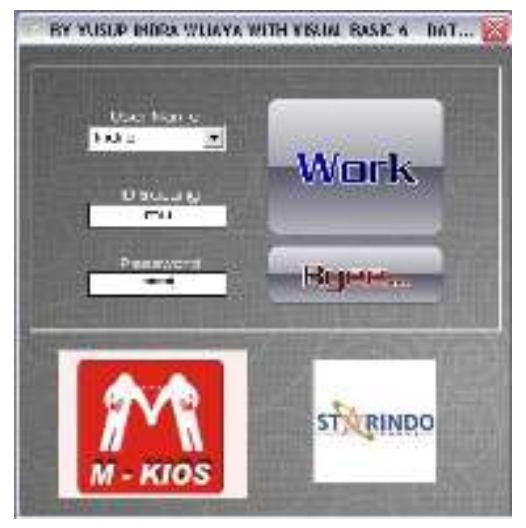

Gambar Login

\section{Tampilan Form Pelanggan}

Form pelanggan berfungsi untuk mengentri data pelanggan yang berisi ID Pelanggan sebagai id untuk memudahkan pengguna input transaksi yang berdasarkan id pelanggan dan bukan berdasarkan nama pelanggan jadi pelanggan harus mengingat id pelanggan masing - masing pada setiap kali melakukan transaksi pembelian, nama pelanggan adalah nama ponsel / outlet, alamat adalah tempat outlet itu berjualan, chip pelanggan adalah chip yang digunakan untuk transaksi penjualan ke pelanggan outlet tersebut, status pelanggan yang terdiri reseller (rs) dan sub dealer bayangan (sdb), dan id gudang yang berperan memberitahukan bahwa pelanggan tersebut adalah terdaftar di gudang yang mana. Pelanggan mempunyai batasan maksimal pada tiap - tiap gudang yaitu 120 pelanggan baik itu berstatus rs atatupun sdb. Dan pelanggaan diinput bersarkarkan gudang masing - masing. Tampilan form pelanggan ditunjukan oleh gambar berikut.

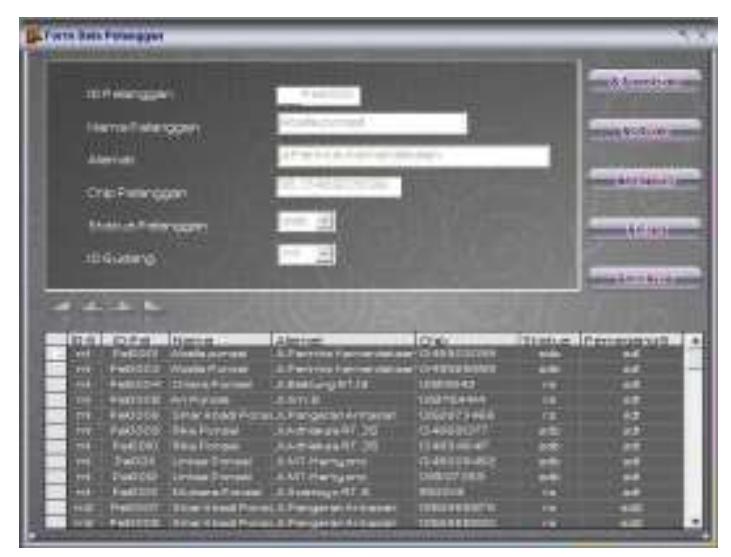

Gambar Form Pelanggan

\section{Tampilan Form Supplier}

Form supplier berfungsi untuk mengentry data supplier, yang berisi ID Supplier, nama supplier dan keterangan. Supplier adalah pemasok barang / stok voucher dari supplier langsung masuk ke AD / gudang master umum (mu). Tampilan form supplier ditunjukan oleh gambar ini.

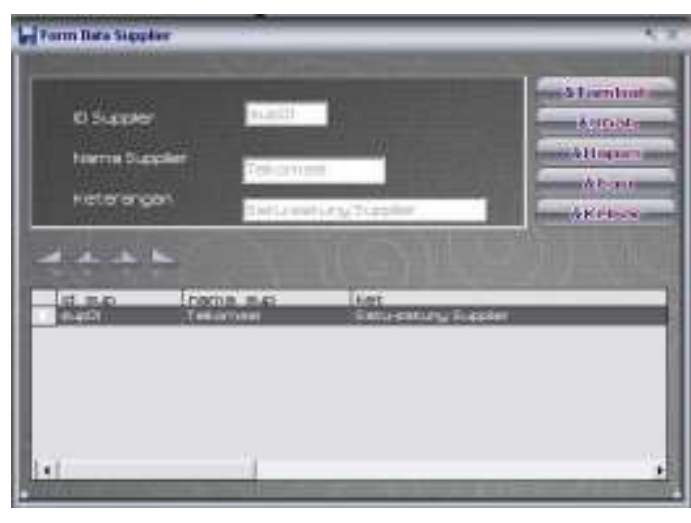

Gambar Form Supplier

\section{Tampilan Form Voucher}

Form voucher berfungsi untuk mengentry data voucher, yang berisi ID voucher, nama voucher, harga beli, harga jual rs, harga jual sdb, keterangan. Dan sampai saat ini sudah terdapat 11 macam jenis voucher. Tampilan form voucher ditunjukan oleh gambar berikut. 


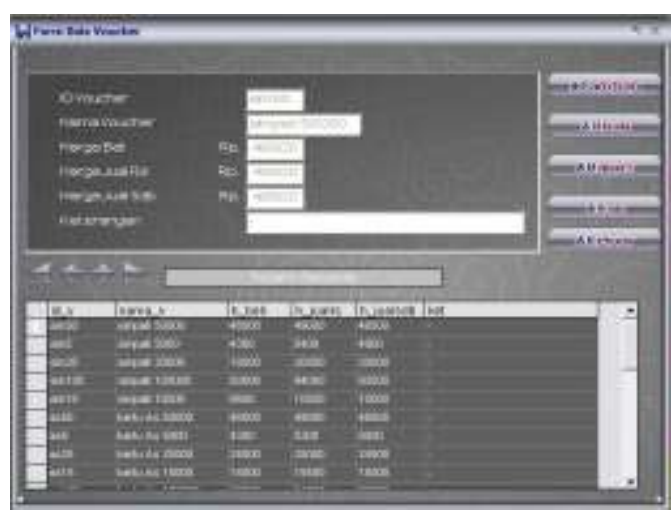

Gambar Form Voucer

\section{Tampilan Form Gudang}

Form gudang berfungsi untuk mengentry data gudang, yang berisi ID gudang, nama gudang, pemegang gudang, nama pemegang, chip gudang, keterangan . Dan sampai saat ini terdapat 1 gudang master umum dan 7 gudang biasa. Tampilan form gudang ditunjukan oleh gambar berikut.

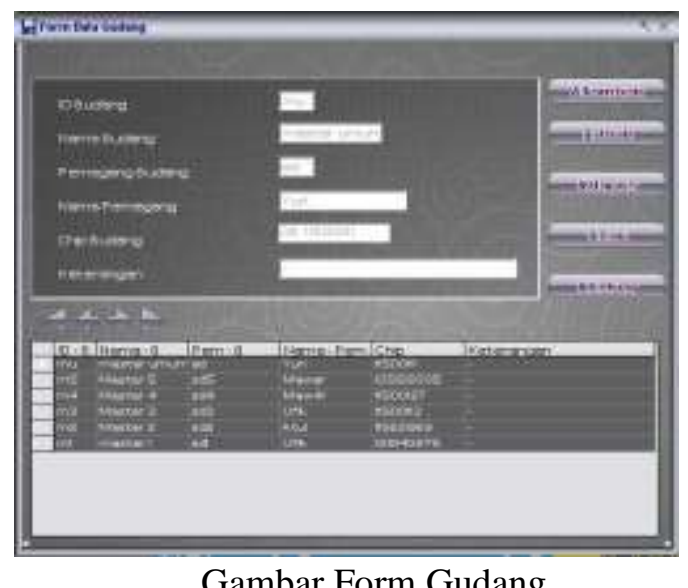

Tampilan Form Stok

Form stok berfungsi untuk mengentry data stok awal dan dapat juga ditambah, diubah, dihapus, dan pencarian. yang berisi nomor stok, tanggal stok, id gudang, id voucher, stok dan stok minimum. Menu form stok ini hanya AD yang dapat mengakses agar keamaan stok voucher terjaga dengan baik tanpa ada SD yang bisa memanipulasi stok. Tampilan form stok ditunjukan oleh gambar berikut.

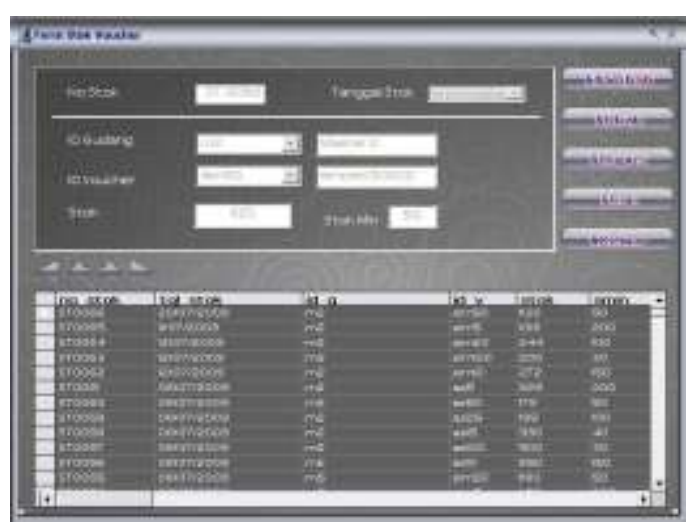

Gambar Form Stok

\section{Tampilan Form Transaksi Pembelian}

Form transaksi pembelian berfungsi untuk mengentry data pembelian. Yang akan menambahkan otomatis stok ke $\mathrm{AD}$ sesuai dengan jenis vouchernya. Pada saat input jumlah pembelian tidak akan dapat melebihi batas, yaitu dibatasi maksimal 30.000 / item . Untuk Nomor Faktur pembelian formatnya adalah 0907901 yaitu 09 adalah tahun, 07 adalah bulan dan 901 adalah angka yang akan diurutkan, sampai bulan / tahun berubah maka urutan angka akan menjadi mulai 901 kembali dengan format bulan / tahun diangka faktur pertama yang bebeda. Form ini hanya AD yang dapat mengakses. Tampilan form transaksi pembelian ditunjukan oleh gambar ini.

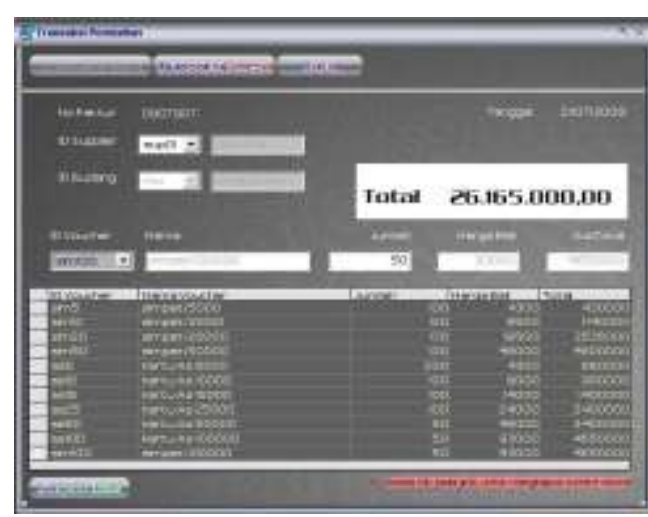

Gambar Form Transaksi Pembelian

\section{Tampilan Form Transaksi Transfer Antar Gudang}

Form transaksi transfer antar gudang berfungsi untuk mengentry data transaksi transfer antar gudang dari AD ke SD. Yang akan menambahkan otomatis stok dari gudang master umum ke master biasa sesuai dengan gudang dan jenis voucher yang ditransfer. Untuk membatasi pada jumlah transfer antar 
gudang maka dibatasi 8.000 / item . Untuk Nomor Faktur TAG formatnya adalah 0907801 yaitu 09 adalah tahun, 07 adalah bulan dan 801 adalah angka yang akan diurutkan, sampai bulan / tahun berubah maka urutan angka akan menjadi mulai 801 kembali dengan format bulan / tahun diangka faktur pertama yang bebeda. Form ini hanya $\mathrm{AD}$ yang dapat mengakses. Tampilan form transaksi transfer antar gudang ditunjukan oleh gambar berikut.

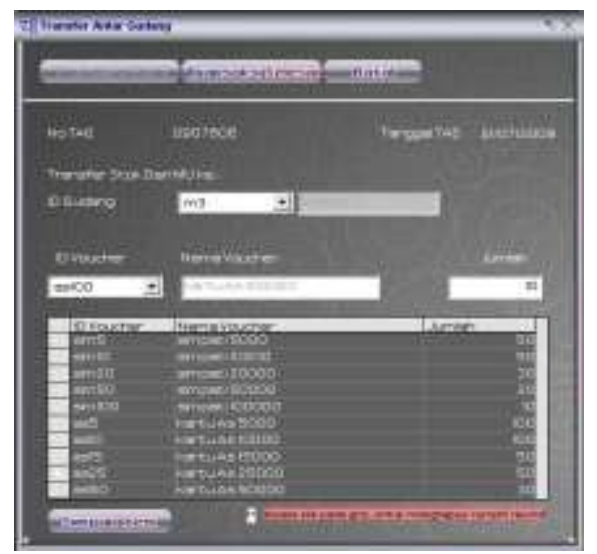

Gambar Transaksi Antar Gudang

\section{Tampilan Form Transaksi Penjualan}

Form transaksi penjualan berfungsi untuk mengentry data penjualan dari SD ke Pelanggan baik rs ataupun sdb sesuai gudang dipegang masing - masing. Yang akan mengurangi otomatis stok gudang tersebut dengan melakukan transaski penjualan. Untuk membatasi pada jumlah penjualan maka dibatasi 500 / item. Id gudang dan nama gudang muncul otomatis sesuai data login dan tidak bisa dirubah secara manual agar mencegah pemakaian id gudang lain untuk transaksi. Pada saat input jumlah, sistem otomatis melakukan pengecekan terlebih dahulu pada stok gudang yang bersangkutan apakah stok yang ingin dijual masih mencukupi sesuai jumlah yang diminta pelanggan. Id pelanggan yang muncul di combobox id pelanggan hanyalah id pelanggan yang bersangkutan dengan gudang tersebut. Jenis pembayaran ada 2 macam yaitu tunai dan kredit, jadi apabila status kredit maka otomatis faktur tersebut langsung masuk ke form transaksi penjualan. Untuk Nomor Faktur penjualan formatnya adalah 0900001 yaitu 09 adalah tahun, dan 00001 adalah angka yang akan diurutkan, sampai tahun berubah maka urutan angka akan menjadi mulai 00001 kembali dengan format tahun diangka faktur pertama yang bebeda. Tampilan form penjualan ditunjukan oleh gambar ini.

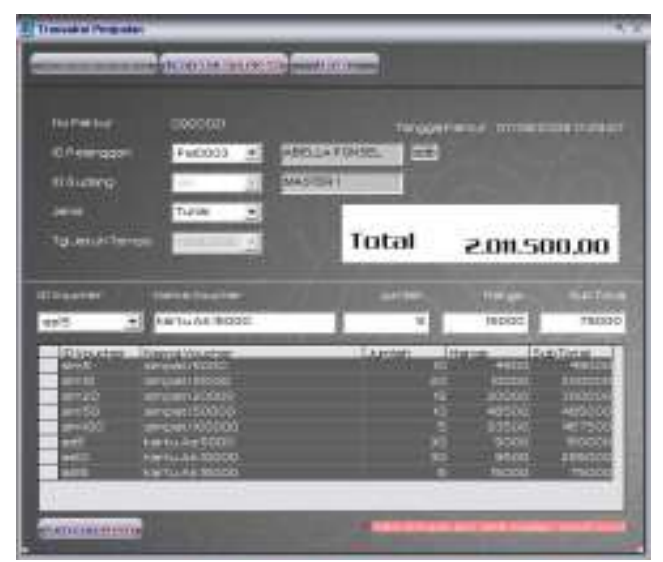

Gambar Form Transaksi Penjualan

\section{Tampilan Form Transaksi Pelunasan}

Form transaksi pelunasan berfungsi untuk mengentry data penjualan yang berstatus kredit dijadikan berstatus lunas. Input pelunasan pencarian berdasarkan id pelanggan terlebih dahulu setelah itu baru memilih nomor faktur yang ingin dilakukan pelunasan, dan apabila status dari kredit menjadi tunai maka data akan masuk ke dalam tabel piutang. Untuk Nomor Faktur Piutang formatnya adalah 0907001 yaitu 09 adalah tahun, 07 adalah bulan dan 001 adalah angka yang akan diurutkan, sampai bulan / tahun berubah maka urutan angka akan menjadi mulai 001 kembali dengan format bulan / tahun diangka faktur pertama yang bebeda. Tampilan form transaksi pelunasan ditunjukan oleh gambar ini.

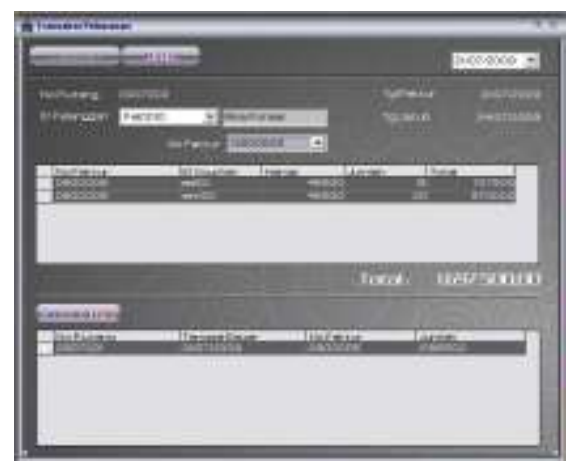

Gambar Form Transaksi Pelunasan

\section{Tampilan Form Reset Nomor Faktur}

Form reset nomor faktur berfungsi untuk menghapus semua nomor faktur, baik nomor faktur penjualan, nomor faktur pembelian, nomor faktur transfer antar gudang, dan nomor faktur piutang. Tapi sebelum 
melakukan reset nomor faktur sebaiknya database dibackup terlebih dahulu di tempat yang aman karena reset di sini adalah menghapus semua isi dalam table tersebut. Tampilan form reset nomor faktur ditunjukan oleh gambar berikut.

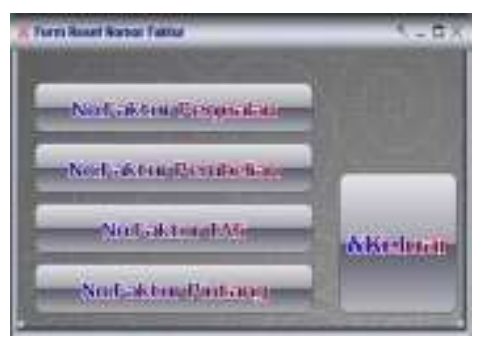

Gambar Form Reset Nomor Faktur

\section{Tampilan Form Pengguna}

Form pengguna berfungsi untuk mengentry data pengguna aplikasi berdasarkan gudang masing - masing yang dipegang. Yang berwenang untuk form ini hanya $\mathrm{AD}$. Tampilan form pengguna ditunjukan oleh gambar berikut.

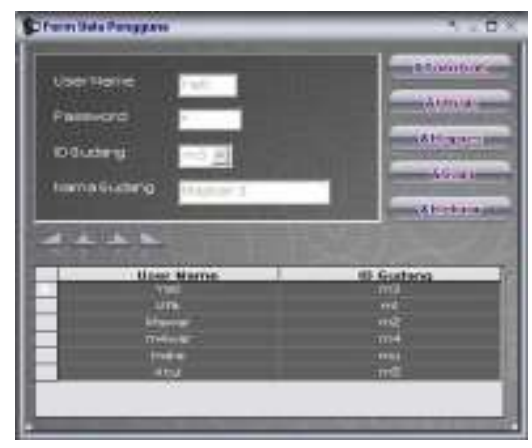

Gambar Form Pengguna

\section{Tampilan Form Ubah Password}

Form ubah password berfungsi untuk mengubah password pengguna aplikasi berdasarkan gudang masing - masing yang dipegang dan harus mengetahui password lama agar dapat merubah password. Tampilan form ubah password ditunjukan oleh gambar ini.

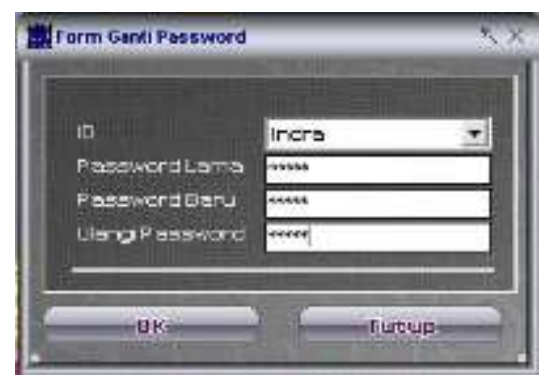

Gambar Form Ubah Password

\section{Tampilan Output}

\section{Tampilan Laporan Penjualan}

Laporan penjualan bertujuan untuk dapat mengetahui berapa banyak transaksi penjualan yang dilakukan berdasarkan periode tertentu, per nomor faktur, per id pelanggan, per id gudang dan per id voucher. Sehingga didapatkan laporan penjualan yang lengkap. Tampilan form laporan penjualan ditunjukan oleh gambar di bawah ini dan laporan penjualan ditunjukan oleh gambar berikut.

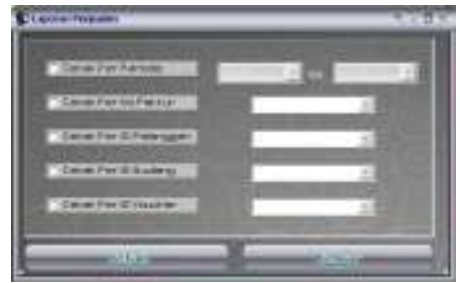

Gambar Form Laporan Penjualan

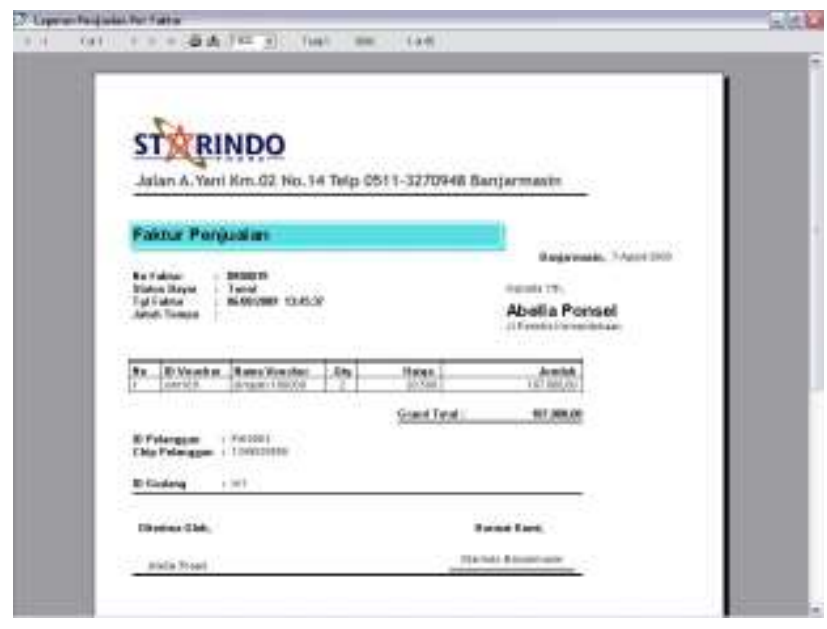

Gambar Laporan Penjualan

\section{Tampilan Laporan Pembelian}

Laporan pembelian bertujuan untuk mengetahui berapa banyak transaksi penjualan yang dilakukan berdasarkan periode tertentu dan per nomor faktur. Tampilan form laporan pembelian ditunjukan oleh gambar di bawah ini dan laporan pembelian ditunjukan oleh gambar berikut.

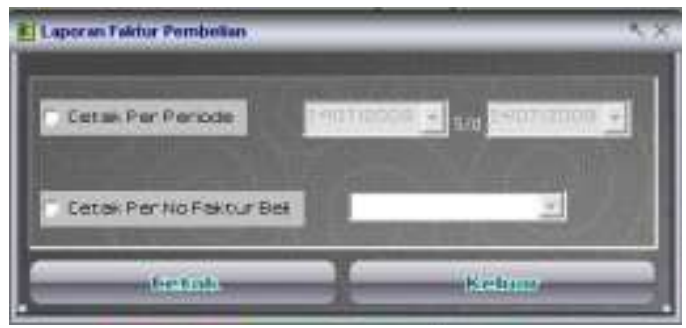

Gambar Form Laporan Pembelian 


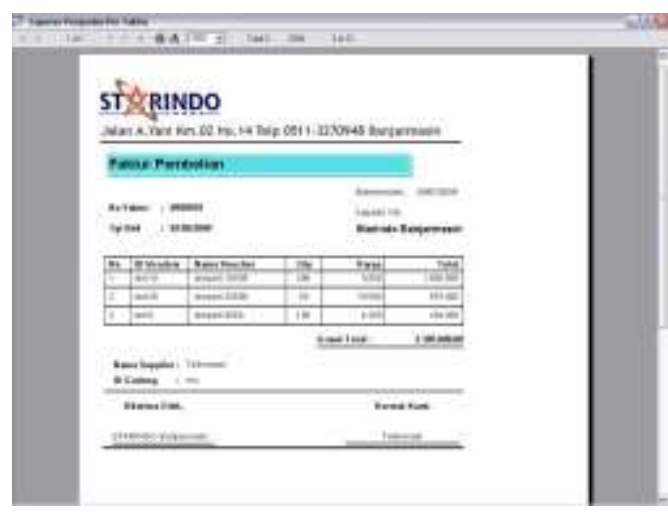

Gambar Laporan Pembelian

\section{Tampilan Laporan Piutang dan Jatuh Tempo}

Laporan piutang dan jatuh tempo bertujuan untuk mengetahui masa piutang itu sudah jatuh tempo / belum, yang dapat dilihat berdasarkan periode tertentu dan per id gudang dan cetak semua. Tampilan form laporan piutang ditunjukan oleh gambar di bawah dan laporan piutang ditunjukan oleh gambar berikut.

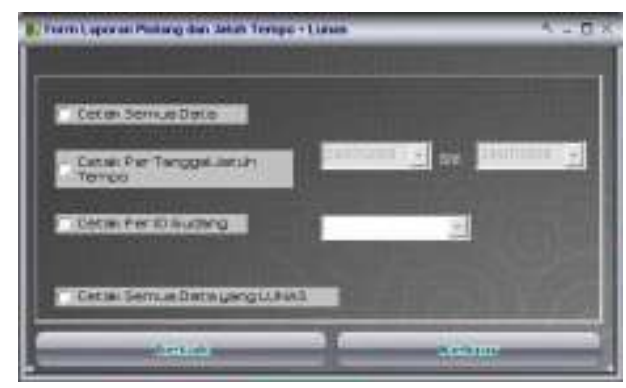

Gambar Form Laporan Piutang

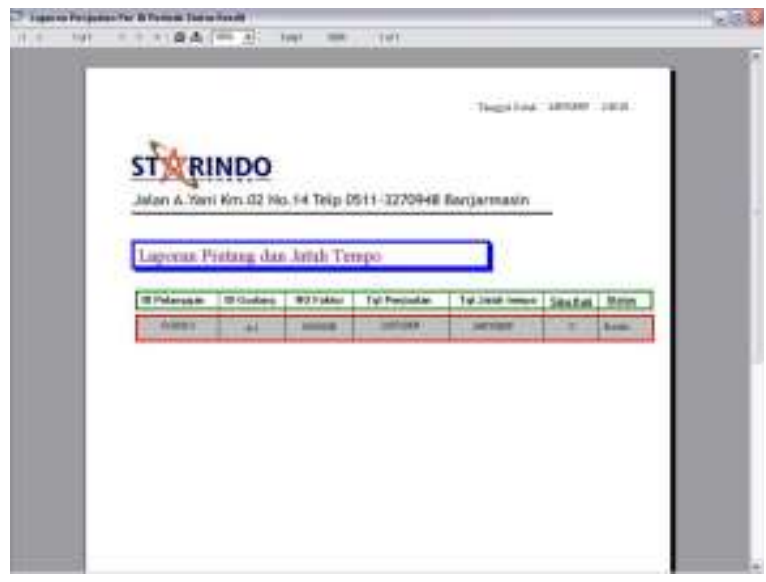

Gambar Laporan Piutang

\section{Tampilan Laporan Transfer Antar Gudang}

Laporan transfer antar gudang bertujuan untuk mengetahui jumlah stok yang masuk kepada SD dari AD. Yang dapat dicetak per periode tertentu, per id gudang, dan cetk semua. Tampilan form laporan TAG ditunjukan oleh gambar di bawah dan laporan TAG ditunjukan oleh gambar berikut.

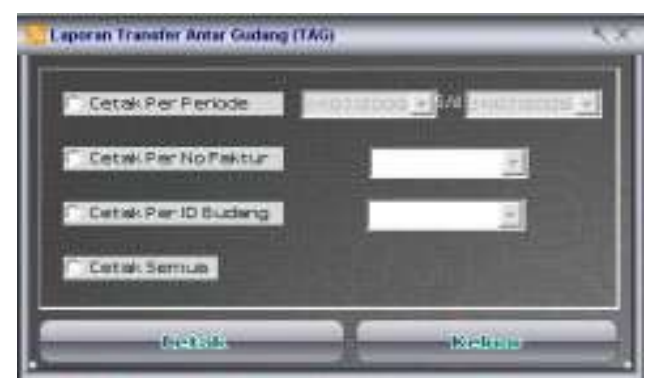

Gambar Form Transfer Antar Gudang

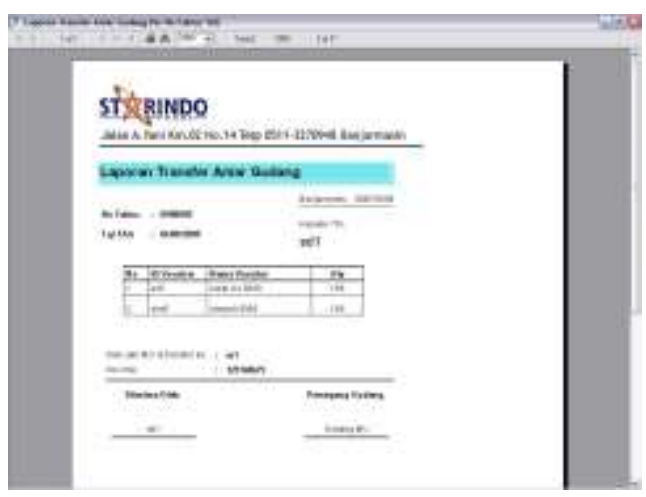

Gambar Laporan Transfer Antar Gudang

\section{Tampilan Laporan Pelanggan}

Laporan pelanggan untuk mengetahui data pelanggan secara detail. Yang dapat dicetak per id gudang, per status pelanggan dan cetak semua. Tampilan form laporan pelanggan ditunjukan oleh gambar di bawah dan laporan pelanggan ditunjukan oleh gambar berikut.

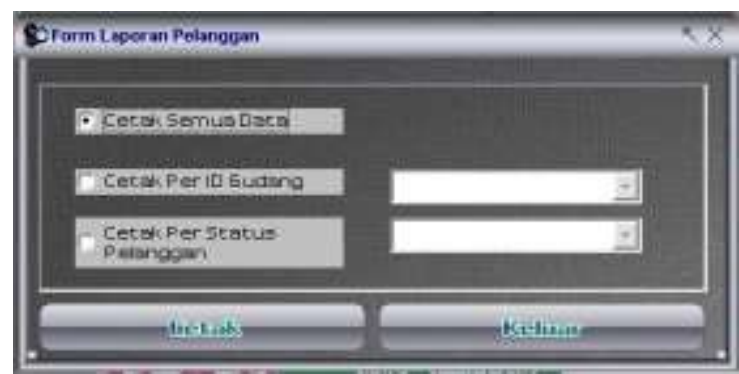

Gambar Form Pelanggan 


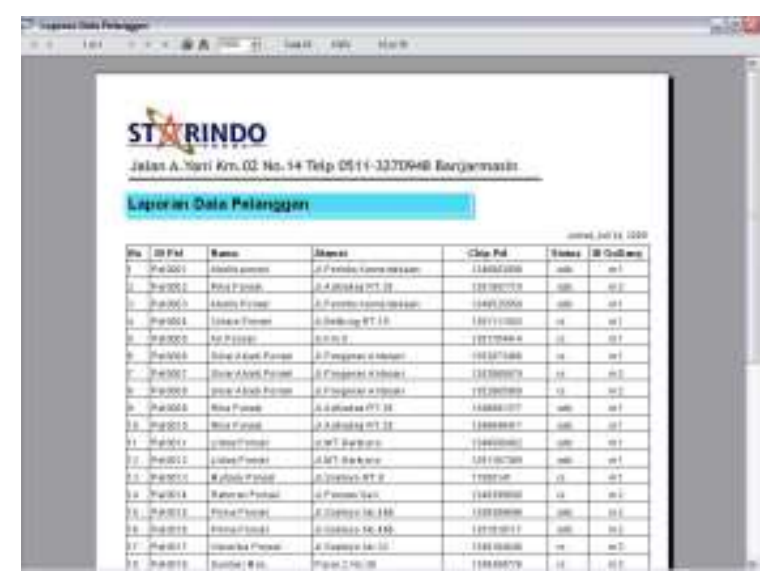

Gambar Laporan Pelanggan

Dan beberapa laporan penting lainnya seperti Laporan supplier, Laporan gudang, Laporan Voucer, Laporan peringkat pelanggan, Laporan statistik, Laporan laba rugi rs, Laporan laba rugi sdb, Laporan stok masuk, Laporan stok keluar, Laporan stok akhir.

\section{KESIMPULAN}

Dari permasalahan yang telah dibahas pada bab - bab sebelumnya, maka dapat disimpulkan bahwa :

1. Keakuratan informasi yang dihasilkan dengan sistem yang dijalankan secara manualisasi belum bisa dipertanggung jawabkan secara penuh, karena banyak item data yang perlu diolah sehingga seringkali terjadi kesalahan yang dilakukan oleh karyawan.

2. Sistem yang dijalankan secara manual akan mengakibatkan kerugian baik dalam waktu dan tenaga yang dibutuhkan, juga dalam hal pelayanan kepada pelanggan menjadi sering salah dan terlambat karena membutuhkan waktu yang lama dalam proses pengolahan data. Hal tersebut mengakibatkan perusahaan sulit bersaing dengan perusahaan sejenis yang sudah menerapkan sistem komputerisasi secara khusus.

3. Dengan proses yang sudah terkomputerisasi seraca khusus maka diharapkan akan membantu bagian merketing dalam pembuatan laporan transaksi - transaksi dengan cepat, tepat dan akurat.

\section{Saran}

Dari kesimpulan di atas maka dapat diberi saran - saran sebagai berikut :

1 .

Menerapkan sistem

komputerisasi yang khusus untuk pengolahan data-data yang kompleks pada sistem yang baru untuk menggantikan sistem yang sedang berjalan yang masih secara manual.

2. Sebaiknya database dalam beberapa periode tertentu dilakukan backup di tempat yang aman dan diburning, agar apabila database mengalami kerusakan ataupun hilang, data yang penting masih ada.

3. Rancangan sistem ini selaras dengan perkembangan zaman dapat dikembangkan dengan menambahkan fitur - fitur tambahan yang dianggap perlu seperti aplikasi yang langsung terhubung dengan handphone yang digunakan untuk transaksi yang dapat melakukan transfer stok ke pelanggan secara otomatis sesuai dengan inputannya dan yang lainnya sesuai dengan kebutuhan perusahaan yang akan datang.

\section{REFERENSI}

[1] Ario Kusumo, Suryo, 2002. Pemrograman Database dengan Visual Basic 6.0, Penerbit Elex Media Komputindo, Jakarta.

[2] Daryanto, 2003. Belajar Komputer Visual Basic, Penerbit Yrama Widya, Malang.

[3] Ladamidin Bin Al-Bahra, 2005. Analisis dan Desain Sistem Informasi, Penerbit Graha Ilmu, Tangerang.

[4] Sekolah Tinggi Manajemen Informatika dan Komputer Indonesia Banjarmasin.2008. Buku Panduan Karya Ilmiah Proposal Skripsi dan PKL.

[5] Taofik Soleh, Redi, 2006. Aplikasi Penjualan Menggunakan VB 6.0 dan Navicat MySQL. Penerbit Elex Media Komputindo, Jakarta. 